\title{
PENGARUH KOMPETENSI TEKNIS, DISIPLIN DAN KOMPENSASI TIDAK LANGSUNG TERHADAP KINERJA ANGGOTA PROVOS RESIMEN III PASUKAN PELOPOR KORPS BRIMOB POLRI
}

\author{
Sumar'; Soehardi²; Zahara Tussoleha Rony3; Beti Nurbaiti4 \\ Fakultas Ekonomi dan Bisnis Universitas Bhayangkara Jakarta Raya ${ }^{1,2,3,4}$ \\ sumar315@gmail.com; soehardi@dsn.ubharajaya.ac.id ${ }^{2}$; zararony@gmail.com³; \\ bettysigit@gmail.com ${ }^{4}$
}

\begin{abstract}
ABSTRAK
Penelitian ini ditujukan untuk menguji pengaruh kompetensi teknis, disiplin, dan kompensasi tidak langsung trerhadap kinerja anggota Provos Resimen III Pas Pelopor sejumlah 119 responden. Pengolahan data dilakukan menggunakan metode Structural Equation Modeling (SEM) dengan Sofware Lisrel full version edisi 8.8. Penelitian ini menggunakan metode kuantitatif dalam pelaksanaannya meliputi data, analisis dan interpretasi tentang arti dan data yang diperoleh. Hasil analisis menunjukkan bahwa kompetensi teknis dan disiplin berpengaruh terhadap kinerja anggota Provos sedangkan kompensasi tidak langsung tidak berpengaruh terhadap kinerja anggotaProvos. Temuan empiris tersebut mengindikasikan bahwa kompetensi teknis berpengaruh signifikan terhadap kinerja anggotaProvos dengan nilai koefisien sebesar 0,45; disiplin berpengaruh signifikan terhadap kinerja anggotaProvos dengan nilai koefisien sebesar 0,37; dan kompensasi tidak langsung tidak berpengaruh signifikan terhadap kinerja anggotaProvos dengan nilai koefisien sebesar 0,13.
\end{abstract}

Kata kunci: kompetensi teknis, disiplin, kompensasi tidak langsung dan kinerja

\section{ABSTRACT}

This study was aimed at examining the effect of technical competence, discipline, and indirect compensation on the performance of members of the Paspelopor Regiment III Province, a number of 119 respondents. Data processing was performed using the Structural Equation Modeling (SEM) method with the full version 8.8 of SoftwareLisrel. This research uses quantitative methods in its implementation including data, analysis and interpretation of the meaning and data obtained. The results of the analysis show that technical competence and influence on the performance of Provincial members while compensation has no effect on the performance of Provincial members. The empirical findings indicate that technical competence has a significant effect on the performance of Provincial members with a coefficient of 0.45; discipline has a significant effect on the performance of Provincial members with a coefficient value of 0.37 ; and indirect compensation has no significant effect on the performance of Provincial members with a coefficient value of 0.13 
Keywords: technical competence, discipline, indirect compensation and performance

Diterima: 12 September 2020; Direvisi: 19 September 2020; Diterbitkan: 1 Oktober 2020

\section{PENDAHULUAN}

Sumber daya manusia merupakan faktor terpenting di dalam suatu organisasi. setiap organisasi harus senantiasa meningkatkan kualitas kinerja sumber daya manusianya untuk tercapainya tujuan yang telah ditetapkan (Evi Lastiani. 2014). Sumber daya manusia merupakan salah satu unsur pelaksana dalam kegiatan organisasi yang bertugas dan bertanggung jawab menjalankan kegiatan-kegiatan operasional organisasi. Dalam melaksanakan tugas seorang karyawan memerlukan suatu ketekunan dalam bekerja, cekatan, memiliki keahlian dan kemampuan dalam melaksanakan tugas. (Wardhani and Wajdi, 2017). Faktor manusia merupakan modal utama yang perlu diperhatikan oleh organisasi atau pemimpin, manusia memang berjiwa kompleks dan sangat pelik untuk dipahami karena sangat berbeda dengan mesin dan peralatan lainnya (A.A.Anwar Prabu, 2013). Dengan demikian mereka menganggap sumber daya manusia sebagai aset paling berharga dari sebuah organisasi. Keberadaan provos di Resimen III Paspelopor, sebagai aparat penegak hukum dan disiplin dituntut untuk bekerja efektif dan efisien dalam rangka memaksimalkan tugas pokok dan peran provos sebagai penegak disiplin anggota Brimob Polri agar tidak terjadi pelanggaran hukum yang dilakukan oleh personil Brimob Polri di lingkungan Resimen III Pasukan Pelopor.

Provos adalah unsur pelaksana staf di pimpin oleh kepala seksi provos disingkat Kasi provos yang berada di bawah komandan Resimen (Danmen) Paspelopor dan dalam pelaksanaan tugasnya seharihari berada di bawah kendali wakil komandan Resimen (Wadanmen) Paspelopor.

Polri adalah kepolisian nasional yang merupakan satu kesatuan dalam melaksanakan peran memelihara keamanan dan ketertiban masyarakat, menegakkan hukum, serta memberikan perlindungan, pengayoman dan pelayanan kepada masyarakat dalam rangka terpeliharanya keamanan dalam negeri sedangkan provos adalah satuan fungsi pada Brimob Polri yang bertugas membantu pimpinan untuk membina dan menegakkan hukum serta memelihara tata tertib kehidupan anggota Brimob Polri di jajaran Pasukan pelopor (Perkap o2 tahun 2016 tentang penyelesaian pelanggaran disiplin polri) Personil fungsi provos saat ini berjumlah 120 personil dengan lingkup tanggung jawabnya pada Mako Pasukan Pelopor dan jajarannya terdiri dari 3 (tiga) Resimen antara lain Resimen I Paspelopor, Resimen II Paspelopor dan Resimen III Paspelopor, Peran provos sangat penting dalam suatu organisasi khususnya di jajaran Paspelopor sebagai salah satu fungsi pembantu pimpinan dalam rangka penegakkan disiplin anggota Brimob Polri agar mampu menjadi satuan yang berkompeten, profesionalime, dan tertib hukum. Provos mempunyai tugas pokok dan fungsinya sebagai penegak hukum dan tata tertib yang berlaku, menyelenggarakan pelayanan dan penerimaan laporan atau pengaduan masyarakat terkait dengan pelanggaran anggota Brimob Polri dan PNS 
di jajaran Paspelopor, menyelenggarakan pembinaan serta rehabilitasi, melakukan pengawasan umum, memeriksa dan melaksanakan proses hukum bagi anggota Brimob Polri yang melakukan pelanggaran hukum dilingkungan Resimen III Paspelopor sebagaimana yang telah diatur dalam peraturan pemerintah republik indonesia nomor 2 tahun 2003, tanggal 1 desember 2003 tentang peraturan disiplin anggota Polri dan juga Peraturan Kapolri nomor 14 tahun 2011 tentang Kode Etik Profesi Polri. Namun demikian tugas tidak berjalan sesuai dengan aturan yang telah ditetapkan karena kinerja provos belum optimal sehingga masih terjadi pelanggaran-pelanggaran disiplin, kode etik maupun pelanggaran pidana yang dilakukan oleh anggota di jajaran Pasukan Pelopor.

Berdasarkan data dari observasi lapangan menunjukkan bahwa Mako Pasukan Pelopor sebanyak 1 pelanggaran yaitu perkara tindak pidana, Resimen I sebanyak 10 pelanggaran, Resimen II sebanyak 11 pelanggaran diantaranya pelanggaran disiplin sebanyak 7 perkara dan pelanggaran Kode Etik Polri (KKEP) sebanyak 4 perkara, dan juga pada Resimen III sebanyak 44 pelanggaran diantaranya pelanggaran disiplin Polri ada 38 perkara, pelanggaran Kode Etik Polri (KKEP) sebanyak 1 perkara dan pelanggaran tindak pidana 5 perkara.

Data pelanggaran yang terjadi pada bulan Januari hingga Desember 2018 menunjukkan bahwa target organisasi untuk mencapai zero (o) pelanggaran tidak tercapai dan kinerja anggota provos Resimen III Paspelopor menurun drastis yakni terjadi pelanggaran sebanyak 44 pelanggaran dibandingkan dengan Mako Paspelopor hanya 1 pelanggaran, Resimen I sebanyak 10 pelanggaran, dan Resimen II sebanyak 11 pelanggaran.

Para anggota yang mengawakinya khususnya anggota provos harus memiliki kompetensi baik teknis maupun non teknis, kompetensi non teknis mengacu pada kemampuan untuk mengendalikan diri dan memacu diri dalam bekerja (Nefina, 2005). Kompetensi non teknis meliputi karakteristik individual seperti tingkah laku dan kepribadian seseorang. Kompetensi teknis adalah kemampuan anggota dalam bidang teknis tertentu untuk pelaksanaan tugas masing-masing, maka dari itu anggota provos harus memahami tugas yang diemban masing masing anggota, sehingga sebagai perpanjangan tangan pimpinan dalam menegakkan aturan dapat memberikan saran masukan sebagai salah satu pertimbangan pimpinan dalam pengambilan keputusan khususnya di Resimen III Pasukan Pelopor Korbrimob Polri, demikan juga halnya dengan anggota provos yang ada di Resimen III Pasukan Pelopor Korpbrimob Polri, tidak terlepas dari berbagai kendala dan kekurangan mengingat kurangnya kompetensi teknis dibidang provos diantaranya adalah: Mengoperasionalkan MS world dan XL serta power point untuk membuat suatu laporan. Melakukan serangkaian tindakan pemeriksa provos Polri dalam hal dan menurut cara yang di atur dalam undangundang untuk mencari dan mengumpulkan bukti, yang dengan bukti itu membuat terang tentang pelanggaran disiplin yang terjadi dan guna menemukan Terduga pelanggarnya. Mampu menjadi penyidik untuk melakukan penyidikan terhadap anggota yang melakukan pelanggaran disiplin. Memiliki kemampuan pengawalan dalam rangka memberikan pengamanan, pengawalan baik terhadap kendaraan yang dikawal, maupun pengguna jalan lain yang berada di sekitar kendaraan yang dikawal. 
Mampu menjadi penyelidik untuk melakukan serangkaian tindakan untuk mencari dan menemukan suatu peristiwa yang diduga sebagai pelanggaran disiplin guna menentukan dapat atau tidaknya dilakukan pemeriksaan pelanggaran disiplin.

Anggota provos merupakan salah satu sumber daya yang dikatakan cukup penting dan memiliki kemampuan untuk berkembang dan perlu mendapatkan perhatian dari pimpinan, salah satunya adalah pemberian kompensasi tidak langsung kepada anggotanya, sebab provos akan selalu berhadapan dengan beban tugas yang sangat berat dalam menjalankan tugasnya sebagai penegak hukum anggota Polri. Perhatian organisasi terhadap pemberian kompensasi tidak langsung secara rasional dan adil dapat meningkatkan kinerja anggota Provos dan jika pemberian kompensasi yang diberikan tidak seimbang atau tidak merata maka kinerja anggota provos akan menurun.

\section{TINJAUAN PUSTAKA}

\section{Kinerja}

Kinerja merupakan catatan outcome yang dihasilkan dari fungsi tertentu atau kegiatan yang dilakukan selama periode waktu tertentu. Sedang kinerja suatu jabatan secara keseluruhan sama dengan jumlah (rata-rata) dari kinerja fungsi atau kegiatan yang dilakukan. Pengertian kinerja disini tidak bermaksud menilai karakteristik individu tetapi mengacu pada serangkaian hasil yang diperoleh selama periode waktu tertentu (Suraj Francis Noronha, 2016).

Ada 6 (enam) indikator yang digunakan antara lain: kualitas, kuantitas, ketepatan waktu, efektivitas, kemandirian dan komitmen kerja. (D. Wardhani, 2017)

Ada 3 (tiga) level kinerja, antara lain yaitu: Kinerja organisasi merupakan pencapain hasil outcome pada level atau unit analisis organisasi. Kinerja pada level organisasi terkait dengan tujuan organisasi, rancangan organisasi dan manajemen organisasi; kinerja proses merupakan kinerja pada proses tahapan dalam menghasilkan produk atau pelayanan. Kinerja pada level proses ini di pengaruhi oleh tujuan proses, rancangan proses dan manajemen proses; dan kinerja individu/pekerjaan merupakan pencapaian atau efektifitas pada tingkat karyawan atau pekerjaan. Kinerja pada proses ini di pengaruhi oleh tujuan pekerjaan, rancangan pekerjaan, dan manajemen pekerjaan serta karakteristik individu. Secara lebih tegas Armstrong dan Baron (2012) mengatakan kinerja merupakan hasil pekerjaan yang mempunyai hubungan kuat dengan tujuan strategis organisasi, kepuasan konsumen dan memberikan konstribusi ekonomi. (Rahmisyari, 2017)

\section{Kompetensi Teknis}

Menurut Mangkunegara (2012), komponen-komponen kompetensi teknis berhubungan dengan pengetahuan, kemampuan dan keterampilan pada bidang tertentu / Teknis yang mempengaruhi secara langsung terhadap kinerjanya, yaitu terdiri dari: pengetahuan dalam bidang teknis tertentu; kemampuan yang dimiliki sesuai dengan keahliannya; keterampilan merupakan keterampilan pada suatu bidang pekerjaan yang menunjukkan sistem atau urutan perilaku yang secara fungsional berhubugan dengan pencapaian tujuan kinerja.

Menurut Walsh et al, (2001) bahwa kompetensi teknis merupakan keterampilan yang luas tentang produksi dan teknologi korporasi yang mendukung organisasi untuk beradaptasi dengan cepat terhadap peluangpeluang yang timbul. Indikator dari kompetensi teknis adalah: tingkat Pendidikan, Pendidikan merupakan persyaratan tingkat pendidikan yang dibutuhkan dalam memegang jabatan dan biasanya berkaitan 
dengan tingkat intelektual, serta tingkat pengetahuan yang diperlukan. Pendidikan yang menjadi persyaratan minimal di dalam sebuah organisasi/perusahaan; pengalaman Kerja, Pengalaman kerja adalah lama seseorang dalam menangani suatu peran atau jabatan tertentu dan melaksanakannya dengan hasil yang baik; dan Kemampuan Menganalisis, Kemampuan untuk memahami situasi dengan memecahkannya menjadi bagian yang lebih kecil, atau mengamati implikasi suatu keadaan tahap demi tahap berdasarkan pengalaman masa lalu.

\section{Disiplin}

Pada dasarnya banyak Indikator yang mempengaruhi tingkat kedisiplinan karyawan suatu organisasi, diantaranya : Tujuan dan kemampuan. Tujuan dan kemampuan ikut mempengaruhi tingkat kedisiplinan karyawan. Tujuan yang akan dicapai harus jelas dan ditetapkan secara ideal serta cukup matang bagi kemampuan karyawan, hal ini berarti bahwa tujuan yang dibebankan kepada karyawan harus sesuai dengan kemampuan karyawan yang bersangkutan, agar dia bekerja sungguhsungguh dan disiplin dalam mengerjakannya

Teladan pimpinan sangat berperan dalam menentukan kedisiplinan karyawan karena pimpinan dijadikan teladan dan panutan oleh para bawahannya. pimpinan harus memberi contoh yang baik, disiplin yang baik, jujur, adil, serta sesuai kata dengan perbuatannya.

Balas jasa atau gaji dan kesejahteraan ikut mempengaruhi kedisiplinan karyawan karena balas jasa akan memberikan kepuasan dan kecintaan karyawan terhadap perusahaan atau pekerjaannya. jika kecintaan karyawan semakin baik terhadap pekerjaan, kedisiplinan mereka akan semakin baik pula.
Keadilan ikut mendorong terwujudnya kedisiplinan karyawan, karena ego dan sifat manusia yang selalu merasa dirinya penting dan di minta diperlakukan sama dengan manusia lainnya. Pengawasan melekat adalah tindakan nyata yang paling efektif dalam mewujudkan kedisiplinan karyawan perusahaan. dengan pengawasan melekat berarti atasan harus aktif dan langsung mengawasi perilaku moral, sikap, gairah kerja, dan prestasi kerja bawahannya.

Sanksi hukuman sanksi hukuman berperan penting dalam memelihara kedisiplinan karyawan dengan sanksi hukuman yang semakin berat karyawan akan semakin takut melanggar aturan aturan perusahaan sikap dan perilaku indisipliner karyawan akan berkurang 7 ketegasan pimpinan dalam melakukan tindakan akan mempengaruhi kedisiplinan karyawan perusahaan hubungan kemanusiaan.

\section{Kompensasi Tidak Langsung}

Nawawi (2013), Zulkarnaen dan Herlina (2018) menggolongkan kompensasi tidak langsung beberapa bagian yaitu: Pembayaran upah untuk waktu tidak bekerja (time-off benefit), meliputi: Istirahat on the job, terdiri dari periode Istirahat, periode makan, periode waktu cuti, hari-hari sakit, liburan dan cuti, alasan lain, misal kehamilan, kecelakaan, upacara pemakaman. Perlindungan terhadap bahaya, (Hazard Protection) meliputi: jaminan pembayaran upah dalam jumlah tertentu selama suatu periode; rencanarencana pension; Tunjangan hari tua, tunjangan pengobatan, pembentukan koperasi atau yayasan yang mengelola kredit karyawan. Program pelayanan 
karyawan (employee service), meliputi: rekreasi; kafetaria; perumahan; beasiswa pendidikan, fasilitas pembelian; konseling finansial dan legal; aneka ragam pelayanan lain.

\section{Kerangka Penelitian}

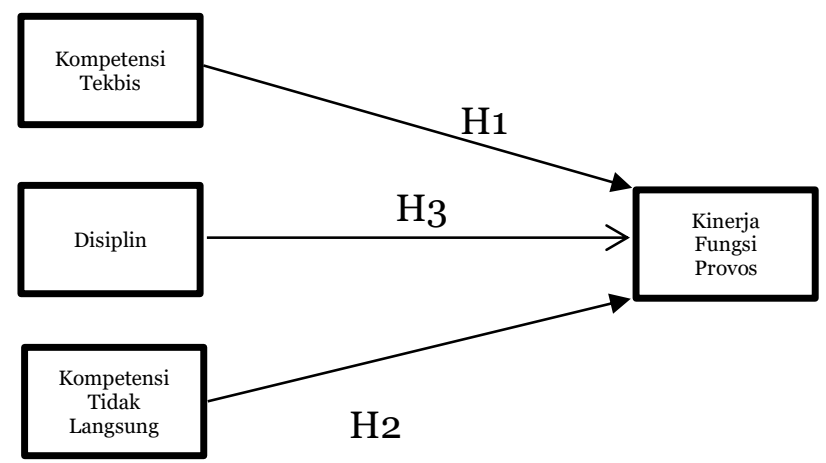

Gambar. 1. Kerangka Penelitian

Hypothesis

H1: Diduga ada pengaruh kompetensi teknis terhadap kinerja

H2: Diduga ada pengaruh disiplin terhadap kinerja

H3: Diduga ada pengaruh kompetensi tidak langsung terhadap kinerja

\section{METODOLOGI PENELITIAN}

Metodologi penelitian yang digunakan adalah kuantitatif dengan analisis uji validitas, reliabilitas, normalitas dan uji t menggunakan software SEM Lisrel versi 8,8. Populasi adalah seluruh anggota Fungsi Provos Resimen III Paspelopor di Jl. Komjen. Pol. M. Yasin Kelapadua, Cimanggis Depok yang berjumlah 120 orang. Sample Jenuh, Menurut Sugiyono (2001) sampling jenuh adalah teknik penentuan sampel bila semua anggota populasi digunakan sebagai sampel. Istilah lain sampel jenuh adalah sensus, dimana semua anggota populasi dijadikan sampel.

\section{HASIL PENELITIAN}

Table 1. Data Umum Responden

\begin{tabular}{ccc}
\hline Keterangan & Personil & Persentase \\
\hline Laki-laki & 119 & $100 \%$ \\
\hline Usia 20-30 tahun & 67 & $56 \%$ \\
\hline Usia 31-40 tahun & 40 & $34 \%$ \\
\hline Usia 41-50 tahun & 12 & $10 \%$ \\
\hline SMA & 93 & $77 \%$ \\
\hline D3 & 2 & $2 \%$ \\
\hline S1 & 24 & $21 \%$ \\
\hline $\begin{array}{c}\text { Masa kerja: 1-10 } \\
\text { tahun }\end{array}$ & 67 & $56 \%$ \\
\hline $\begin{array}{c}\text { 11-20 tahun } \\
\text { > 20 tahun }\end{array}$ & 52 & $43 \%$ \\
\hline
\end{tabular}

Sumber: Data Personil Provos Resimen III Paspelopor 2019

\section{Variabel Laten Eksogen Kompetensi Teknis (KT)}

Berdasarkan gambar 2, table 2 dan 3 ada variabel teramati yang dibuang/dihilangkan karena memiliki nilai Standardized loading factor (SLF) kurang dari 0,5 diantaranya KT8, KT9, KT10 dan KT11. Uji kecocokan model menunjukkan semua variable teramati dalam variable laten KT memiliki kecocokan yang baik, data mendukung model penelitian ini. Dari hasil Uji Validitas Dan Reliabilitas Variabel Laten KT tersebut dapat disimpulkan bahwa semua variabel teramati dalam variabel laten KT memiliki validitas dan reliabilitas yang baik.

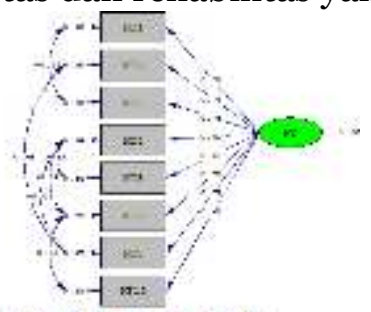

Gambar 2. NiTai Standardized loading factor (SLF) Kompetensi Teknis

Sumber : Pengolahan Data Lisrel 2019 
Table 2. Indikator Goodness of Fit Index

\begin{tabular}{|c|c|c|}
\hline Indikator & $\begin{array}{c}\text { Nilai } \\
\text { Standar } \\
\text { untuk } \\
\text { Kecocokan Baik }\end{array}$ & $\begin{array}{c}\text { Hasil Uji } \\
\text { Kecocokan }\end{array}$ \\
\hline $\begin{array}{c}\text { RMSEA } \\
\text { Root Mean Square } \\
\text { Error of } \\
\text { Approximation }\end{array}$ & $\leq 0,08$ & 0,00 \\
\hline $\begin{array}{c}\text { NFI } \\
\text { Normed Fit Index }\end{array}$ & $\geq 0,90$ & 0,99 \\
\hline $\begin{array}{c}\text { NNFI } \\
\text { Non-Normed Fit } \\
\text { Index }\end{array}$ & $\geq 0,90$ & 1,01 \\
\hline $\begin{array}{c}\text { CFI } \\
\text { Comparative Fit } \\
\text { Index }\end{array}$ & $\geq 0,90$ & 1,00 \\
\hline $\begin{array}{c}\text { IFI } \\
\text { Incremental Fit } \\
\text { Index }\end{array}$ & $\geq 0,90$ & 1,01 \\
\hline $\begin{array}{c}\mathrm{RFI} \\
\text { Relative Fit Index }\end{array}$ & $\geq 0,90$ & 0,98 \\
\hline $\begin{array}{c}\text { Std. RMR } \\
\text { Standardized Root } \\
\text { Mean Square } \\
\text { Residuan } \\
\end{array}$ & $\leq 0,05$ & 0,027 \\
\hline $\begin{array}{c}\text { GFI } \\
\text { Goodness of Fit } \\
\text { Index }\end{array}$ & $\geq 0,90$ & 0,92 \\
\hline $\begin{array}{c}\text { AGFI } \\
\text { Adjusted Goodness } \\
\text { of Fit Index } \\
\text { Sumber : Pengolahan }\end{array}$ & $\begin{array}{c}\quad \geq 0,90 \\
\text { n Data Lisrel } 2010\end{array}$ & 0,90 \\
\hline \multicolumn{3}{|c|}{ Table 3. Uji Validitas dan Reliabilitas } \\
\hline $\begin{array}{cc}\text { Variabel } & S \\
\text { Teramati } & \\
& F \\
\end{array}$ & $\begin{array}{l}\text { tandardized } \\
\text { Loading } \\
\text { Factor (SLR) }\end{array}$ & Error \\
\hline KT1 & 0,72 & 0,48 \\
\hline KT2 & 0,78 & 0,40 \\
\hline KT3 & 0,76 & 0.43 \\
\hline KT4 & 0,60 & 0.64 \\
\hline KT5 & 0,68 & 0.54 \\
\hline KT6 & 0,73 & 0.47 \\
\hline $\mathrm{KT}_{7}$ & 0,73 & 0.47 \\
\hline KT12 & 0,61 & 0.63 \\
\hline $\begin{array}{c}\text { Nilai } \\
\text { Construct } \\
\text { Realiability }\end{array}$ & 0,89 & \\
\hline $\begin{array}{c}\text { Variance } \\
\text { Extracted (VE) }\end{array}$ & 0,50 & \\
\hline
\end{tabular}

Sumber : Pengolahan Data Lisrel 2019

\section{Variabel Laten Eksogen Disiplin (DS)}

Berdasarkan gambar 3 , table 4 dan 5 tidak ada variabel teramati yang dibuang atau dihilangkan karena memiliki nilai Standardized loading factor (SLF) diatas 0,5. Uji kecocokan model menunjukkan semua variable teramati dalam variable laten DS memiliki kecocokan yang baik, hanya 1 indikator dengan kecocokan moderat atau cukup, namun sebagian besar variable teramati dalam variable laten DS memiliki kecocokan yang baik, dengan data mendukung model penelitian ini. Dari hasil Uji Validitas Dan Reliabilitas Variabel Laten DS tersebut dapat disimpulkan bahwa semua variabel teramati dalam variabel laten DS memiliki validitas dan reliabilitas yang baik.

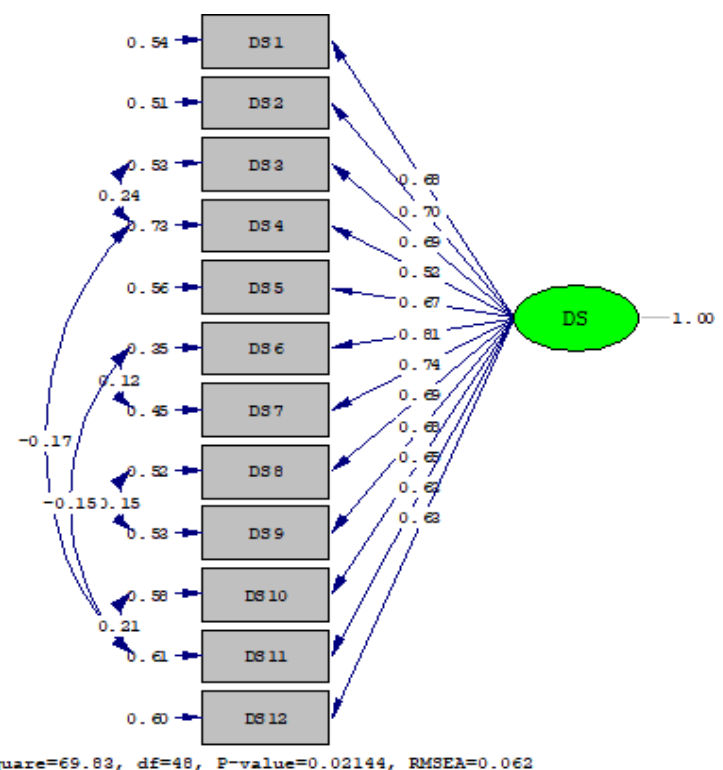

Gambar 3. Nilai SLF Disiplin

Sumber : Pengolahan Data Lisrel 2019

Table 4. Indikator Goodness of Fit Index Indikator

$\begin{array}{cc}\text { Nilai } & \text { Hasil Uji } \\ \text { Standar } & \text { Kecocokan }\end{array}$
untuk

Kecocokan Baik

$\begin{array}{lll}\text { RMSEA } & \leq 0,08 & 0.062\end{array}$

Root Mean Square

Error of

Approximation
NFI
$\geq 0,90$
0.96

Normed Fit Index 


\begin{tabular}{clc}
\hline $\begin{array}{c}\text { NNFI } \\
\text { Non-Normed Fit } \\
\text { Index }\end{array}$ & $\geq 0,90$ & 0.98 \\
\hline $\begin{array}{c}\text { CFI } \\
\text { Comparative Fit } \\
\text { Index }\end{array}$ & $\geq 0,90$ & 0.99 \\
\hline $\begin{array}{c}\text { IFI } \\
\text { Incremental Fit } \\
\text { Index }\end{array}$ & $\geq 0,90$ & 0.99 \\
\hline $\begin{array}{c}\text { RFI } \\
\text { Relative Fit Index }\end{array}$ & $\geq 0,90$ & 0.94 \\
\hline $\begin{array}{c}\text { Std. RMR } \\
\text { Standardized Root } \\
\text { Mean Square } \\
\text { Residuan }\end{array}$ & $\leq 0,05$ & 0.05 \\
\hline $\begin{array}{c}\text { GFI } \\
\text { Goodness of Fit } \\
\text { Index }\end{array}$ & $\geq 0,90$ \\
\hline $\begin{array}{c}\text { AGFI } \\
\text { Adjusted Goodness } \\
\text { of Fit Index }\end{array}$ & $\geq 0,90$ \\
\hline Sumber: Pengolan & 0.90 \\
\hline
\end{tabular}

Sumber : Pengolahan Data Lisrel 2019

Table 5. Uji Validitas dan Reliabilitas

\begin{tabular}{ccc}
\hline $\begin{array}{c}\text { Variabel } \\
\text { Teramati }\end{array}$ & $\begin{array}{c}\text { Standardized } \\
\text { Loading } \\
\text { Factor (SLR) }\end{array}$ & Error \\
\hline DS1 & 0.68 & 0.54 \\
\hline DS2 & 0.70 & 0.51 \\
\hline DS3 & 0.69 & 0.53 \\
\hline DS4 & 0.52 & 0.73 \\
\hline DS5 & 0.67 & 0.56 \\
\hline DS6 & 0.81 & 0.35 \\
\hline DS7 & 0.74 & 0.45 \\
\hline DS8 & 0.69 & 0.52 \\
\hline DS9 & 0.68 & 0.53 \\
\hline DS10 & 0.65 & 0.58 \\
\hline DS11 & 0.63 & 0.61 \\
\hline DS12 & 0.63 & 0.60 \\
\hline $\begin{array}{c}\text { Nilai } \\
\text { Construct } \\
\text { Realiability }\end{array}$ & 0.91 & \\
\hline Variance & 0.50 & \\
Extracted (VE) & & \\
\hline Sumber Penglah Data & \\
\hline
\end{tabular}

Sumber : Pengolahan Data Lisrel 2019

\section{Variabel Laten Eksogen Kompetensi Tidak Langsung (KTL)}

Berdasarkan gambar 4, table 6 dan 7 ada variabel teramati yang dibuang atau dihilangkan karena memiliki nilai Standardized loading factor (SLF) dibawah 0,5 diantaranya KTL 1, KTL8 dan KTL9. Uji kecocokan model menunjukkan semua variable teramati dalam variable laten KTL memiliki kecocokan yang baik, dengan data mendukung model penelitian ini. Dari hasil Uji Validitas Dan Reliabilitas Variabel Laten DS tersebut dapat disimpulkan bahwa semua variabel teramati dalam variabel laten DS memiliki validitas dan reliabilitas yang baik.

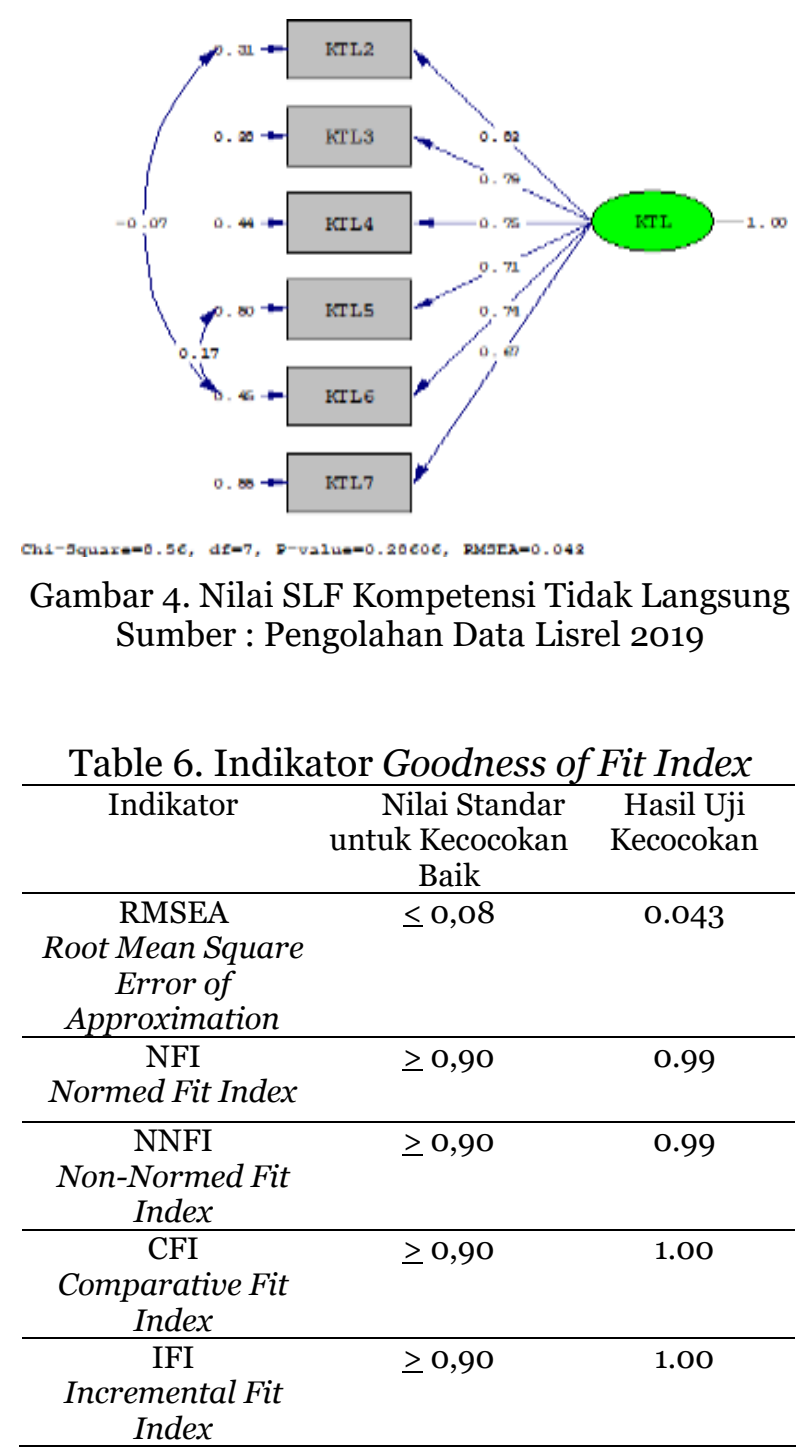




\begin{tabular}{clc}
\hline RFI & $\geq 0,90$ & 0.97 \\
Relative Fit Index & & \\
\hline $\begin{array}{c}\text { Std. RMR } \\
\text { Standardized Root } \\
\text { Mean Square } \\
\text { Residuan }\end{array}$ & $\leq 0,05$ & \\
\hline GFI & & \\
$\begin{array}{c}\text { Goodness of Fit } \\
\text { Index }\end{array}$ & $\geq 0,90$ \\
\hline $\begin{array}{c}\text { AGFI } \\
\text { Adjusted Goodness of } \\
\text { Fit Index }\end{array}$ & $\geq 0,90$ \\
\hline
\end{tabular}

Sumber : Pengolahan Data Lisrel 2019

Table 7. Uji Validitas dan Reliabilitas

\begin{tabular}{ccc}
\hline $\begin{array}{c}\text { Variabel } \\
\text { Teramati }\end{array}$ & $\begin{array}{c}\text { Standardized } \\
\text { Loading } \\
\text { Factor (SLR) }\end{array}$ & Error \\
\hline KTL2 & 0.83 & 0.31 \\
\hline KTL3 & 0.79 & 0.38 \\
\hline KTL4 & 0.75 & 0.44 \\
\hline KTL5 & 0.71 & 0.50 \\
\hline KTL6 & 0.74 & 0.45 \\
\hline KTL7 & 0.67 & 0.56 \\
\hline $\begin{array}{c}\text { Nilai } \\
\text { Construct } \\
\text { Realiability }\end{array}$ & 0.88 & \\
\hline Variance & & \\
Extracted (VE) & 0.60 & \\
\hline Sumber : Pengolahan Data Iisrel &
\end{tabular}

Sumber : Pengolahan Data Lisrel 2019

\section{Variabel Laten Endogen Kinerja (KIN)}

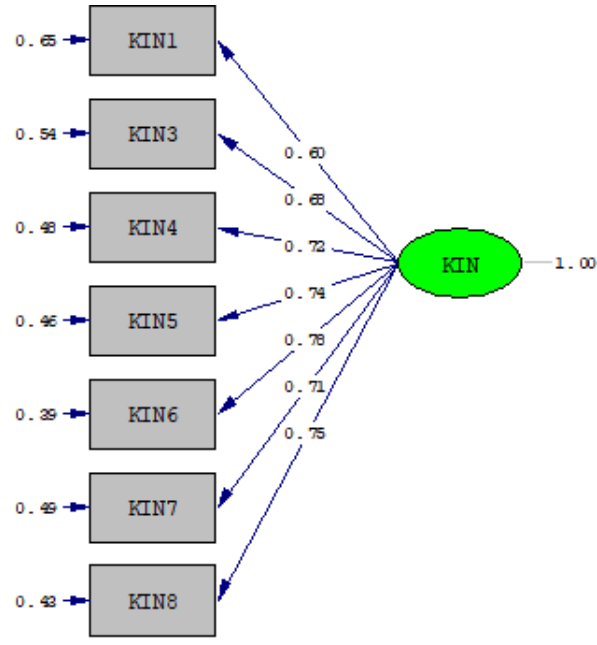

Chi-3quare $=0.96$, df $=14, \mathrm{p}-\mathrm{value}=1.00000, \mathrm{RMSEA}=0.000$

Gambar 5. Nilai SLF Kinerja

Sumber : Pengolahan Data Lisrel 2019

Berdasarkan gambar 5 , table 8 dan 9 ada variabel teramati yang dibuang atau dihilangkan karena memiliki nilai Standardized loading factor (SLF) dibawah 0,5 yaitu KIN2. Uji kecocokan model menunjukkan semua variable teramati dalam variable laten KTL memiliki kecocokan yang baik, dengan data mendukung model penelitian ini. Dari hasil Uji Validitas Dan Reliabilitas Variabel Laten DS tersebut dapat disimpulkan bahwa semua variabel teramati dalam variabel laten DS memiliki validitas dan reliabilitas yang baik.

Table 8. Indikator Goodness of Fit Index

\begin{tabular}{|c|c|c|}
\hline Indikator & $\begin{array}{c}\text { Nilai } \\
\text { Standar } \\
\text { untuk } \\
\text { Kecocokan Baik } \\
\end{array}$ & $\begin{array}{c}\text { Hasil Uji } \\
\text { Kecocokan }\end{array}$ \\
\hline $\begin{array}{c}\text { RMSEA } \\
\text { Root Mean Square } \\
\text { Error of } \\
\text { Approximation }\end{array}$ & $\leq 0,08$ & 0.00 \\
\hline $\begin{array}{c}\text { NFI } \\
\text { Normed Fit Index }\end{array}$ & $\geq 0,90$ & 1.00 \\
\hline $\begin{array}{c}\text { NNFI } \\
\text { Non-Normed Fit } \\
\text { Index } \\
\end{array}$ & $\geq 0,90$ & 1.03 \\
\hline $\begin{array}{c}\text { CFI } \\
\text { Comparative Fit } \\
\text { Index }\end{array}$ & $\geq 0,90$ & 1.00 \\
\hline $\begin{array}{c}\text { IFI } \\
\text { Incremental Fit } \\
\text { Index }\end{array}$ & $\geq 0,90$ & 1.02 \\
\hline $\begin{array}{c}\text { RFI } \\
\text { Relative Fit Index }\end{array}$ & $\geq 0,90$ & 1.00 \\
\hline $\begin{array}{c}\text { Std. RMR } \\
\text { Standardized Root } \\
\text { Mean Square } \\
\text { Residuan } \\
\end{array}$ & $\leq 0,05$ & 0.050 \\
\hline $\begin{array}{c}\text { GFI } \\
\text { Goodness of Fit } \\
\text { Index } \\
\end{array}$ & $\geq 0,90$ & 0.92 \\
\hline $\begin{array}{c}\text { AGFI } \\
\text { Adjusted Goodness } \\
\text { of Fit Index }\end{array}$ & $\geq 0,90$ & 0.90 \\
\hline
\end{tabular}

Sumber: Data Dioleh oleh Peneliti 
Table 9. Uji Validitas dan Reliabilitas

\begin{tabular}{ccc}
\hline $\begin{array}{c}\text { Variabel } \\
\text { Teramati }\end{array}$ & $\begin{array}{c}\text { Standardized } \\
\text { Loading } \\
\text { Factor (SLR) }\end{array}$ & Error \\
\hline KIN1 & 0.60 & 0.65 \\
\hline KIN3 & 0.68 & 0.54 \\
\hline KIN4 & 0.72 & 0.48 \\
\hline KIN5 & 0.74 & 0.46 \\
\hline KIN6 & 0.78 & 0.39 \\
\hline KIN7 & 0.71 & 0.49 \\
\hline KIN8 & 0.75 & 0.43 \\
\hline $\begin{array}{c}\text { Nilai } \\
\text { Construct } \\
\text { Realiability }\end{array}$ & 0,88 & \\
\hline $\begin{array}{c}\text { Variance } \\
\text { Extracted (VE) }\end{array}$ & 0.51 & \\
Sumber : Pengolahan Data Lisrel 2019 &
\end{tabular}

\section{Uji Confirmatory Factor Analysis (CFA)}

Gambar 6. Uji CFA

Berdasarkan gambar 6, table 7 dan 8 menunjukkan bahwa hasil uji kecocokan model untuk semua variable teramati dalam variable laten pada uji CFA memiliki kecocokan yang sangat baik. Uji kecocokan model untuk semua variable teramati dalam variable laten pada uji CFA memiliki kecocokan yang sangat baik (Perfect Fit) dan data mendukung model penelitian. Dari hasil Uji Validitas dan Reliabilitas Variabel Laten CFA dapat disimpulkan bahwa semua variabel teramati dalam variabel laten pada uji CFA memiliki validitas dan reliabilitas yang baik, juga setiap indikator atau dimensi pembentuk masingmasing variable laten menujukkan hasil baik dengan CR diatas 0,70 dan nilai VE diatas 0,30.

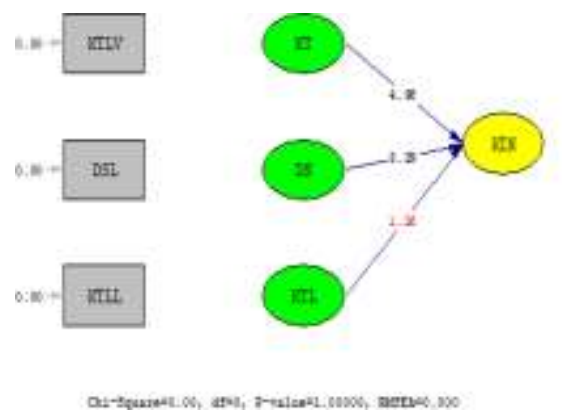

Gambar 6. CFA
Tabel 7. CFA

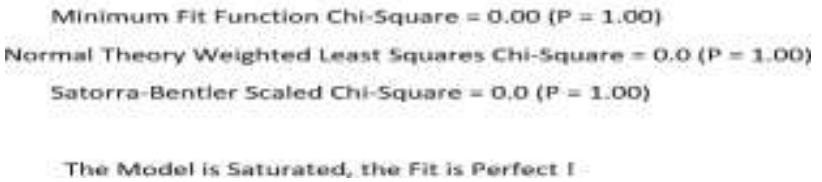

Table 8. Uji Validitas dan Reliabilitas

\begin{tabular}{ccc}
\hline $\boldsymbol{K} \boldsymbol{T}$ & $\mathrm{CR}=0.99$ & $; \mathrm{VE}=0.99$ \\
\hline KTL & 0.99 & 0.01 \\
\hline $\boldsymbol{D S}$ & $\mathrm{CR}=0.99$ & $; \mathrm{VE}=0.99$ \\
\hline $\mathrm{DSL}$ & 0.99 & 0.01 \\
\hline $\boldsymbol{K} \boldsymbol{T L}$ & $\mathrm{CR}=0.99$ & $; \mathrm{VE}=0.99$ \\
\hline KTLL & 0.99 & 0.01 \\
\hline $\boldsymbol{K I N}$ & $\mathrm{CR}=0.99$ & ; VE $=0.99$ \\
\hline KINL & 0.99 & 0.01
\end{tabular}

Sumber: Pengolahan Data Lisrel 2019

\section{Uji Model Struktural atau Uji Hipotesis}

Berdasarkan gambar 7 dan tabel 9 menunjukkan bahwa hipotesis pertama $\mathrm{H} 1$ diterima dan Ho ditolah karena nilai t hitung $(4,98) \geq t$ tabel $(1,96)$, maka dapat diartikan ada pengaruh kompetensi teknis terhadap kinerja. Hipotesis kedua $\mathrm{H} 1$ diterima dan Ho ditolah karena nilai t hitung $(3,29) \geq \mathrm{t}$ tabel $(1,96)$, maka dapat diartikan ada pengaruh disiplin terhadap kinerja. Hipotesis ketiga $\mathrm{H} 1$ ditolak dan Ho diterima karena nilai $t$ hitung $(1,26) \leq \mathrm{t}$ tabel $(1,96)$, maka dapat diartikan tidak ada pengaruh kompensasi tidak langsung terhadap kinerja.

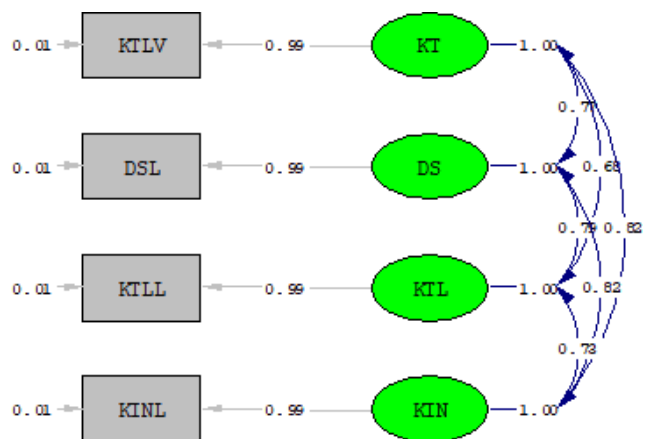

Gambar 7. Uji Model StrukturaI(Uji T)

Chi-square $=0.00, d f=0, P-v a l u e=1.00000$, RMSEA $=0.000$

Gambar 7. Uji Model Struktural 
Tabel 9. Hasil Uji Model Struktural

\begin{tabular}{ccc}
\hline $\begin{array}{c}\text { Hubungan Antara } \\
\text { Variabel }\end{array}$ & $\begin{array}{c}\text { Nilai T } \\
\text { Hitung }\end{array}$ & $\begin{array}{c}\text { Nilai Koefisien } \\
\text { Standar }\end{array}$ \\
\hline $\begin{array}{c}\text { Kompentensi Teknis } \\
\text { (KT) terhadap }\end{array}$ & 4.98 & 0.45 \\
Kinerja (KIN) & & \\
\hline $\begin{array}{c}\text { Disiplin (DS) } \\
\text { terhadap Kinerja } \\
\text { (KIN) }\end{array}$ & 3.29 & 0.37 \\
\hline $\begin{array}{c}\text { Kompensasi Tidak } \\
\text { Langsung (KTL) } \\
\text { terhadap Kinerja } \\
\text { (KIN) }\end{array}$ & 1.26 & 0.13 \\
Sumber: Pengolahan Data Lisrel 2019 & \\
\hline
\end{tabular}

Pembahasan

\section{Kompetensi Teknis (KT) terhadap Kinerja}

Pengujian hipotesis pertama dilakukan untuk menguji pengaruh variabel Kompetensi Teknis (KT) terhadap Variabel Kinerja (KIN). Pembuktian ada tidaknya pengaruh yang signifikan dilakukan dengan membandingkan nilai t- statistik hasil dari perbandingan dengan t-tabel. Berdasarkan tabel 4.7, diketahui nilai $t$ hitung lebih besar dari t tabel, yaitu 4,98 lebih besar dari 1,96. Hal ini dapat disimpulkan bahwa Kompetensi Teknis (KT) terbukti berpengaruh signifikan terhadap Variabel Kinerja (KIN), artinya jika Kompetensi Teknis meningkat, maka semakin meningkat kinerja pada fungsi Provos, dan jika kompetensi Teknis menurun maka kinerja fungsi Provos menurun.

Hasil penelitian ini sesuai dengan hasil penelitian yang telah dilakukan oleh seorang mahasiswa Program Studi Magister Manajemen Pascasarjana Universitas Tadulako sulawesi tengah yang bernama Hamlan Daly dalam, 2015 yang menyatakan bahwa Kompetensi Teknis berpengaruh positif dan signifikan terhadap Kinerja pada pegawai badan pemberdayaan perempuan dan Keluarga berencana daerah Provinsi Sulawesi Tengah.

\section{Disiplin terhadap Kinerja}

Pengujian hipotesis kedua dilakukan untuk menguji pengaruh variabel Disiplin (DS) terhadap Variabel Kinerja (KIN). Pembuktian ada tidaknya pengaruh yang signifikan dilakukan dengan membandingkan nilai $\mathrm{t}$ statistik hasil dari perbandingan dengan t-tabel. Berdasarkan tabel 4.7, diketahui nilai t hitung lebih besar dari t tabel, yaitu 3,29 lebih besar dari 1,96. Hal ini dapat disimpulkan bahwa Disiplin (DS) terbukti berpengaruh signifikan terhadap Variabel Kinerja (KIN), artinya jika Disiplin baik, maka kinerja akan baik, dan jika Disiplin menurun maka kinerja fungsi Provos menurun.

Hasil penelitian ini sesuai dengan hasil penelitian yang telah dilakukan oleh Ernita Sibarani yang menyatakan bahwa semakin tinggi disiplin kerja maka kinerja karyawan akan meningkat. Dan juga hasil uji f menunjukkan bahwa disiplin kerja secara simultan berpengaruh signifikan terhadap kinerja karyawan pada pada Rumah Sakit Swasta Lancang Kuning Pekanbaru .

\section{Kompensasi Tidak langsung terhadap Kinerja}

Pengujian hipotesis ketiga dilakukan untuk menguji pengaruh variabel Kompensasi Tidak langsung (KTL) terhadap Variabel Kinerja (KIN). Pembuktian ada tidaknya pengaruh yang signifikan dilakukan dengan membandingkan nilai t- statistik hasil dari perbandingan dengan t-tabel. Berdasarkan hasil penelitian diketahui nilai t hitung lebih kecil dari $\mathrm{t}$ tabel, yaitu 1,26 lebih kecil dari 1,96. Hal ini dapat disimpulkan bahwa Kompensasi Tidak langsung (KTL) tidak berpengaruh signifikan terhadap Variabel Kinerja (KIN), artinya ada tidaknya Kompensasi Tidak langsung (KTL), maka tidak mempengaruhi kinerja fungsi Provos. 


\section{Kesimpulan dan Saran}

\section{Kesimpulan}

Kompetensi Teknis (KT) terbukti berpengaruh signifikan terhadap Variabel Kinerja (KIN), artinya jika Kompetensi Teknis meningkat, maka kinerja pada fungsi Provos akan meningkat, sebaliknya jika kompetensi Teknis menurun maka kinerja fungsi Provos juga akan menurun, untuk itu kemampuan teknis dalam menjalankan tugas pokok dan fungsinya sebagai penegak disiplin harus berkompeten pada bidangnya salah satunya yaitu kompetensi teknis sebagai penyidik. sehingga dengan kemampuan teknis yang dimilikinya akan mendukung keberhasilan tugas yang di laksanakan didalam pekerjaannya sebagai Provos.

Disiplin (DS) terbukti berpengaruh signifikan terhadap Variabel Kinerja (KIN), artinya jika Disiplin baik, maka kinerja akan baik, dan jika Disiplin menurun maka kinerja fungsi Provos juga menurun, sebagai penegak disiplin anggota Brimob fungsi Provos tidak terlepas dari disiplin, semakin tinggi Disiplin yang dimilikinya maka akan menunjang keberhasilan fingsi provos dalam Kinerjanya yaitu menegakkan disiplin di lingkunagannya. hal ini sesuai dengan fakta dilapangan bahwa disiplin adalah harga mati bagi Provos dalam tugasnya sebagai penegak disiplin.

Kompensasi Tidak langsung (KTL) dalam penelitian ini tidak berpengaruh signifikan terhadap Variabel Kinerja (KIN), artinya ada tidaknya Kompensasi Tidak langsung (KTL), maka tidak berpengaruh terhadap kinerja fungsi Provos hal ini sesuai fakta dilapangan bahwa sebagai anggota Provos sudah siap mentalya untuk mendahulukan kepentingan negara dari pada kepentingan Pribadi sebagai mana ketika mendapatkan tugas pengamanan pemilu presiden 2019 maka sudah siap untuk tidak mengambil cuti bersama untuk merayakan hari raya idul fitri bersama keluarga, melainkan tetap menjalankan tugas sesuai dengan perintah atasan. Untuk menguatkan hipotesa ini peneliti juga melakukan uji Anova menggunakan sofware SPSS yang menunjukkan bahwa seluruh responden berjenis kelamin laki-laki dengan usia lebih didominasi pada usia 20 sampai dengan 30 tahun dan masa kerja dibawah 10 tahun artinya bahwa doktrin sebagai anggota Polri untuk mendahulukan kepentingan bangsa dan negara diatas kepentingan pribadinya masih kuat sehingga untuk tidak mendapatkan hak untuk cuti tidak begitu berpengaruh dibandingkan dengan anggota lainnya yang usianya di atas 30 tahun, yang mana rata-rata mereka sudah berkeluarga dan lebih membutuhkan cuti dibandingkan mereka yang usianya dibawah 30 tahun atau masa kerja dibawah 10 tahun hal ini sesuai dengan fenomena atau fakta di lapangan

\section{Saran}

Fungsi Provos Resimen III Paspelopor harus melakukan evaluasi secara periodik terkait Kompetensi Teknis, sehingga anggota Fungsi Provos dalam meningkatkan kopetensi teknis Provos dapat mengikuti pendidikan kejuruan bidang Provos yang kemudian dapat diaplikasikan di lingkungan kerjanya. Perlu konsistensi baik dari manajemen maupun dari pimpinan organisasi agar evaluasi terus berjalan. Dari evaluasi ini fungsi Provos dapat mengukur kemampuan teknis yang dimilikinya.

Fungsi Provos Resimen III Paspelopor harus melakukan evaluasi secara periodik terkait Disiplin, sehingga anggota dapat memiliki kesadaran dalam mematuhi serta menaati aturan yang ada kemudian diaplikasikan di lingkungan kerja. Perlu konsistensi baik dari manajemen maupun dari pimpinan organisasi agar evaluasi terus berjalan. Dari evaluasi ini anggota dapat semakin paham dan sadar terhadap segala aturan yang berlaku di Fungsi Provos Resimen III Paspelopor.

Hasil penelitian ini bukan ukuran yang mutlak, sehingga faktor-faktor yang berpengaruh terhadap Kinerja bisa berbeda keadaannya di tempat lain yang mempunyai tingkat permasalahan yang berbeda 


\section{Daftar Pustaka}

Abraham (2017).“ Pengaruh Kompetensi Kerja terhadap Kinerja Karyawan Di Kantor PT. Kitadin Tenggarong Seberang” eJournal Administrasi Negara Volume 5, (Nomor 2 ) 2017: 5789 -5802 ISSN 0000-0000, ejournal.an.fisip- unmul.ac.id (C) Copyright 2017.

Antonacopoulou dan Gerald (2016) dalam Madapusi (2018) (2017)." The Influence of Technical Competence Factors in ERP System Implementations" IOSR International Journal of Business and Management (IOSR-JBM) e-ISSN: 2278487X, p-ISSN: 2319-7668. Volume 20, Issue 2. Ver. VIII (February. 2018).

Armstrong, michael, (2009). Handbook of performance Management. London: Kogan Page.

Bagibet 2002, dalam Sutrisno (2016) "Manajemen Sumber Daya Manusia". Cetakan ke -6 , Jakarta , penerbit Prenadamedia Group.

Bernandin dan Russell (2006) dalam Khumaedi (2016) "pengaruh disiplin dan motivasi kerja terhadap kinerja pegawai pada dinas sentra operasi terminal Pt.angkasa pura II”. Jurnal Ilmiah Manajemen dan Bisnis Volume 2, Nomor 1, Maret 2016.

Bernaddin dan Russel (2011) dalam Priansa 2017) "Manajemen Kinerja Pegawai". Cetakan pertama ,Bandung, penerbit CV. Pustaka Setia.

Boyatzis dalam Hutapea dan Nurianna Thoha (2014) dalam Madapusi (2018) (2017).“ The Influence of Technical Competence Factors in ERP System Implementations" IOSR International Journal of Business and Management (IOSR-JBM) e-ISSN: 2278-487X, p-ISSN: 2319-7668. Volume 20, Issue 2. Ver. VIII (February. 2018).

Byars dan Rue (2017) dalam Madapusi (2018) (2017)." The Influence of Technical Competence Factors in ERP System Implementations" IOSR International Journal of Business and Management (IOSR-JBM) e-ISSN: 2278-487X, pISSN: 2319-7668. Volume 20, Issue 2. Ver. VIII (February. 2018).
Camara (2011) dalam Degson Ferreira (2016) "The Impact of Compensation Systems on the motivation of Teachers of a Higher Education Institution", International Journal of Business Management and Economic Research(IJBMER), Vol 7(6),2016, 793803 www.ijbmer.com 793 ISSN:22296247

Covey, Roger dan Rebbeca Meril (1994) dalam Maarif, (2017).“ pengaruh kompetensi teknis, pendidikan dan pelatihan berkelanjutan, komitmen organisasi, dan pengalaman kerja terhadap kualitas hasil pemeriksaan pada aparat pengawas internal pemerintah inspektorat kabupaten aceh barat" Jurnal Megister Akuntansi ISSN 2302-0164 Pascasarjana Universitas Syiah Kuala.

Dessler (1998) dalam Sunuharyo dkk (2016) "pengaruh kompensasi langsung dan kompensasi tidak langsung terhadap motivasi kerja karyawan dan kinerja karyawan", Jurnal Administrasi Bisnis (JAB)|Vol. 37 No. 1 Agustus 2016| administrasibisnis.studentjournal.ub.a c.id.

Dingle (dalam Halil zaim (2013). " analyzing the effects of individual competencies on performance: a field study in services industries in turkey" International Journal of Gliobal Strategic \begin{tabular}{l|l|l|l} 
Management | V. 7 & N. 2 & 2013-
\end{tabular} December | isma.info | 67-77 | DOI: 10.20460/JGSM.2013715668.

Dr. Malayu S.P. Hasibuan, dalam R.Supomo (2018). "Manajemen Sumber Daya Manusia”. Cetakan ke -6 , Bandung , penerbit Y.Rama Widya.

Drs.Syefi'i Aksal. (2011) 'Job Description dilingkungan Korbrimob Polri', (12 Mei 2011).

Emmyah (2009) "pengaruh kompetensi dan pelatihan terhadap kinerja karyawan PT. Adaro energy tbk", jurnal Telaah Bisnis ,Volume 16, Nomor 2, Desember 2015.

Evi Lastiani. 2014. Pengaruh disiplin terhadap kinerja anggota pada satlantas polresta pekanbaru. Jurnal Ilmiah Ekonomi dan Bisnis Vol. 11, No. 2, September 2014: $353-367$ ISSN: $1829-9822$. 
Fahlevi, (2017) 'Pengaruh Kompetensi Petugas Terhadap Kinerja Pelayanan Kesehatan Dipuskesmas Peureumeuekabupaten Aceh Barat', pp. 978-979. Available at: http://eprints.uad.ac.id/5421/1/34.

Fauziah, S., Sunuharyo, B. S. and Utami, H. N. (2016) 'Pengaruh Kompensasi Langsung Dan Kompensasi Tidak Langsung Terhadap Motivasi Kerja Karyawan Dan Kinerja Karyawan', Jurnal Administrasi Bisnis, 37(1), pp. 178-187. Available at: https://www.google.co.id/url?sa=t\&sou rce=web\&rct=j\&url=http://administr asibisnis.studentjournal.ub.ac.id/index. php/jab/article/download/1446/1825 \&ved=2ahUKEwjTz6vK5 PaAhWHmp QKHUmgAJUQFjABegQICRAB\& usg=AOvVawoKp7bBa24vVwftfn 7 W6jA V.

Flippo yang dikutip Handoko (2012) dalam Setiyadi (2016), "the effect of compensation and work motivation on employee performance at semen indonesia limited company", International Journal of Academic Research and Reflection Vol. 4, No. 3, 2016 ISSN 2309-0405.

Halil Zaim (2013).“ analyzing the effects of individual competencies on performance: a field study in services industries in turkey" International Journal of Global Strategic Management | V. 7 | N. 2 | 2017-December | isma.info | 67-77 | DOI: 10.20460/JGSM.2013715668.

Hasibuan (2013) dalam Zulkarnaen dan Herlina (2018) "pengaruh kompensasi langsung dan kompensasi tidak langsung terhadap kinerja karyawanBagian staff operasional pt pranata jaya abadi banjaran", Jurnal Ilmiah Manajemen Ekonomidan Akuntansi vol. 2 no. 2 januari - juni 2018 E-ISSN: 2621-5306 Vol. Iii no. 1 januari - juni 2018 P-ISSN: 2541-5255.

Hamlan Daly (2015) "pengaruh kompetensi, disiplin dan kompensasi terhadap kinerja pegawai badan pemberdayaan perempuan dan keluarga berencana daerah provinsi sulawesi tengah" eJurnal Katalogis, Volume 3 Nomor 1,
Januari 2015 hlm 84-94 ISSN: 23022019.

Hasibuan (2005) dalam Lastriani (2014) "pengaruh disiplin terhadap kinerja anggota pada satlantas polresta pekanbaru" Jurnal Ilmiah Ekonomi dan Bisnis Vol. 11, No. 2, September 2014: $353-367$ ISSN: $1829-9822$.

Hair et al, (2006) "multivariate data analysis with reading". Pretice hall, Englewood Cliffs, New jersey.

Ilman Ataunur dan Eny Ariyanto (2015) "pengaruh kompetensi dan pelatihan terhadap kinerja karyawan PT. Adaro energy tbk", jurnal Telaah Bisnis,Volume 16, Nomor 2, Desember 2015.

Lastriani, E. (2014) 'PENGARUH DISIPLIN TERHADAP KINERJA ANGGOTA PADA SATLANTAS POLRESTA PEKANBARU Elvi Lastriani Sekolah Tinggi Ilmu Ekonomi Dharma Putera', 11(2), pp. 353-367.

Latainer 1995, dalam Sutrisno (2016). "Manajemen Sumber Daya Manusia". Cetakan ke -6 , Jakarta , penerbit Prenadamedia Group.

Mangkunegara (2014) "Manajemen Sumber Daya Mnausia Perusahaan” Yogyakarta : Pustaka Pelajar., Oktober 2014.

Mangkuprawira (2011) dalam Simangunsong (2016) "Pengaruh Kompensasi Langsung dan Kompensasi Tidak Langsung Terhadap Semangat Kerja Karyawan di PT. Bandar Abadi Batam", Jurnal Akuntansi, Ekonomi dan Manajemen Bisnis Vol. 4, No. 2, December 2016, 142149 P-ISSN: $2337-7887$.

Manguntara (2016).“ peningkatan kompetensi pegawai dalam menunjang prestasi kerja pegawai pada dinas perindustrian dan perdagangan provinsi sulawesi tenggara" ISSN 2303-1174 A.C. Dusauw., V.P.K. Lengkong., G.M. Sendow. Peningkatan Kompetensi 511 Jurnal EMBA Vol.4 No.5 September 2016, Hal. 551-510.

Martini (2018)" The Influence of Competency on Employee Performance through Organizational Commitment Dimension" IOSR Journal of Business 
and Management (IOSR-JBM) e-ISSN: 2278-487X, p-ISSN: 2319-7668. Volume 20, Issue 2. Ver. VIII (February. 2018), PP 29-37.

Mc Clelland (dalam Abraham, 2017:5791).“ Pengaruh Kompetensi Kerja terhadap Kinerja Karyawan Di Kantor PT. Kitadin Tenggarong Seberang” eJournal Administrasi Negara Volume 5, (Nomor 2 ) 2017: 5789 -5802 ISSN 0000-0000, ejournal.an.fisip-unmul.ac.id Copyright 2017.

Mangkunegara (2012) dalam abraham (2017) "Pengaruh Kompetensi Kerja terhadap Kinerja Karyawan Di Kantor PT. Kitadin Tenggarong Seberang” eJournal Administrasi Negara Volume 5, (Nomor 2 ) 2017: 5789 -5802 ISSN 0000-0000, ejournal.an.fisip-unmul.ac.id Copyright 2017.

Maarif, (2017) 'pengawas internal pemerintah inspektorat kabupaten aceh', 6(2), pp. $75-85$.

Moeheriono, (2014) Pengukuran Kinerja Berbasis Kompetensi. Cetakan ke-2. Jakarta: Penerbit Raja Grafindo Persada.

Mubarok, (2018)" The Influence of Training, Competence, and Motivation on Employees Performance of Workers Social Security Agency in Banten Province, Indonesia" Journal of Economics and Sustainable Development www.iiste.org ISSN 22221700 (Paper) ISSN 2222-2855 (Online) Vol.9, No.4, 2018.

Nawawi (2008) dalam Simangunsong (2016) "Pengaruh Kompensasi Langsung dan Kompensasi Tidak Langsung Terhadap Semangat Kerja Karyawan di PT. Bandar Abadi Batam", Jurnal Akuntansi, Ekonomi dan Manajemen Bisnis Vol. 4, No. 2, December 2016, 142-149 P-ISSN: 2337-7887

Nawawi, (2011) dalam Nurtcahjono dkk (2014) "pengaruh kompensasi langsung dan kompensasi tidak langsung terhadap motivasi kerja karyawan", Jurnal Administrasi Bisnis (JAB)|Vol. 12 No. 2 Juli

2014 administrasibisnis.studentjournal.ub.a c.id

Notoadmodjo, (2009) dalam Nurtcahjono dkk (2014) "pengaruh kompensasi langsung dan kompensasi tidak langsung terhadap motivasi kerja karyawan", Jurnal Administrasi Bisnis (JAB)|Vol. 12 No. 2 Juli 2014 administrasibisnis.studentjournal.ub.a c.id.

Noe,Premeaux, (1999) dalam Priansa 2017)

"Manajemen Kinerja Pegawai". Cetakan pertama ,Bandung, penerbit CV. Pustaka Setia. Noronha, (2016)."Implementing employee performance management System: a scoping review" International Journal of Management and Applied Science, ISSN: 2394-7926 Volume-2, Issue-5, May.2016.

Priansa, (2017) "Manajemen Kinerja Pegawai". Cetakan pertama ,Bandung , penerbit CV. Pustaka Setia.

Prasetyo dan Jannah (2008) "The effect of career development and working discipline towards working satisfaction and employee performance in the regional office of ministry of religious", international journal of scientific \& technology research volume 5, issue 03 , march 2016 ISSN 2277-861

R. Supomo (2018). "Manajemen Sumber Daya Manusia”. Cetakan ke -6 , Bandung, penerbit Y.Rama Widya.

Rahmisyari, (2017) "Pengaruh Kompetensi dan Lingkungan Kerja Terhadap Kinerja Pegawai" Jurnal Manajemen Bisnis Indonesia Vol. 5, Nomor 1, Oktober 2017.

Rande, (2016: 106) "pengaruh kompetensi terhadap kinerja pegawai pada dinas perhubungan, komunikasi dan informatika kabupaten mamuju utara" e Jurnal Katalogis, Volume 4 Nomor 2, Februari 2016 hlm 101-109 ISSN: 23022019.

Rande, (2016) "pengaruh kompetensi terhadap kinerja pegawai pada dinas perhubungan, komunikasi dan informatika kabupaten mamuju utara" e Jurnal Katalogis, Volume 4 Nomor 2, Februari 2016 hlm 101-109 ISSN: 23022019. 
Rivai (2004) dalam Lastriani (2014) "pengaruh disiplin terhadap kinerja anggota pada satlantas polresta pekanbaru" Jurnal Ilmiah Ekonomi dan Bisnis Vol. 11, No. 2, September 2014: 353 - 367 ISSN: $1829-9822$.

Rony, Zahara (2016). "Siapa harus pergi, siapa harus tinggal, Jakarta, Pusat studi sumber daya manusia (PSSDM).

Rony, Zahara (2017). "Siap fokus, siap menulis skripsi, tesis, disertasi, Jakarta, Pusat studi sumber daya manusia (PSSDM).

Sastrohadiwiryo, dalam R.Supomo (2018). "Manajemen Sumber Daya Manusia". Cetakan ke -6, Bandung, penerbit Y.Rama Widya.

Setiadi, R. U. and Setiadi, P. B. (2016) 'The effect of compensation and work motivation on employee performance at semen indonesia limited company', International Journal of Academic Research and Reflection, 4(3), pp. 6485 .

Shahzadi (2014) "Impact of Employee Motivation on Employee Performance" International Journal of Business and Management" www.iiste.org ISSN 22221905 (Paper) ISSN 2222-2839 (Online) Vol.6, No.23, 2014.

Singodimedjo (2000) dalam Sutrisno (2016) "Manajemen Sumber Daya Manusia". Cetakan ke -6, Jakarta , penerbit Prenadamedia Group.

Sri Lastanti (2015) dalam Madapusi (2018) (2017).“ The Influence of Technical Competence Factors in ERP System Implementations" IOSR International Journal of Business and Management (IOSR-JBM) e-ISSN: 2278-487X, pISSN: 2319-7668. Volume 20, Issue 2. Ver. VIII (February. 2018).

Sudarmanto, (2014). Kinerja dan Pengembangan Kompetensi SDM. Yogyakarta : Pustaka Pelajar.

Sutrisno (2016). "Manajemen Sumber Daya Manusia”. Cetakan ke -6 , Jakarta , penerbit Prenadamedia Group.

Sugiyono (2001). "Prosedur Penelitian : Suatu Pendekatan Praktis, edisi revisi 2010. Jakarta : Rineka Cipta
Somayeh et al. (2013) dalam Jeffrey dan Zein (2017) 'the effects of achievement motivation, learning Discipline and learning facilities on student Learning outcomes, ISSN: 2230-9926 International Journal of Development ResearchVol. o7, Issue, o9, pp.1547115478, September, 2017

Sofyan (2016) "The effect of career development and working discipline towards working satisfaction and employee performance in the regional office of ministry of religious affairs in south sulawesi”, international journal of scientific \& technology research volume 5, issue o3, march 2016 ISSN2277-8616

Simamora (2006) dalam Sunuharyo dkk (2016) "pengaruh kompensasi langsung dan kompensasi tidak langsung terhadap motivasi kerja karyawan dan kinerja karyawan", Jurnal Administrasi Bisnis (JAB) $\mid$ Vol. $37 \quad$ No. 1 Agustus 2016|administrasibisnis.studentjournal .ub.ac.id

Suryadana (2015) "pengelolaan sumber daya manusia berbasis kinerja", Bandung Penerbit Cv. Alfabeta .

Suwatno (2016) "Manajemen Sumber daya manusia dalam organisasi publik dan bisnis", Bandung Penerbit Cv. Alfabeta.

Terry 2002, dalam Sutrisno (2016) "Manajemen Sumber Daya Manusia”. Cetakan ke -6 , Jakarta , penerbit Prenadamedia Group.

Trotter (2014) dalam Madapusi (2018) (2017).“ The Influence of Technical Competence Factors in ERP System Implementations" IOSR International Journal of Business and Management (IOSR-JBM) e-ISSN: 2278-487X, pISSN: 2319-7668. Volume 20, Issue 2. Ver. VIII (February. 2018).

Walsh et al (2001).“ Faktor - Faktor yang mempengaruhi kompetensi teknis" https://www.ejurnal.com/2014/o2/faktor-faktor-yang empengaruhi_19.html

Wardhani, D. P. and Wajdi, M. F. (2017) 'Dampak Lingkungan Kerja Terhadap Kinerja Profesi Polisi Di Kepolisian Resort Ponorogo',(September 2017). 
Wardhani (2017) "Dampak Lingkungan Kerja Terhadap Kinerja Profesi Polisi Di Kepolisian Resort Ponorogo" e-Jurnal KNAPPPTMA KE-6, September 2017 ISBN: 978-602-50710-2-7.

Wibowo (2016). 'manajemen kinerja'memahami kinerja, jakarta Eedisi ke 5. Wijanto, (2008) 'Structural Equation Modeling, Konsep dan tutorial, Yogyakarta.

Zuamah, st. (2017) 'analisis pengaruh kompetensi teknis, Kompetensi sosial, dan kualitas interaksi terhadap kualitas layanan dalam meningkatkan citra perusahaan dan kepuasan konsumen'.

Zulkarnaen, W. and Herlina, R. (2018) 'Pengaruh Kompensasi Langsung Dan Kompensasi Tidak Langsung Terhadap Kinerja Karyawan Bagian Staff Operasional Pt Pranata Jaya Abadi Banjaran', Jurnal Ilmiah Manajemen, Ekonomi, \& Akuntansi (MEA), 2(2), pp. 90-114. doi: 10.31955/jimea.vol2.iss2.pp9o-114 